\title{
Usulan Perbaikan dan Perancangan Ulang Food Truck Berdasarkan Metode Kano dan Ditinjau dari Segi Ergonomi
}

\author{
Marthin Ferdinan Raja Hasian Lumban Toruan ${ }^{1 *}$, Elty Sarvia ${ }^{2}$ \\ ${ }^{1,2}$ Program Studi Teknik Industri, Universitas Kristen Maranatha, Bandung, Indonesia \\ ('martinferdinan71@yahoo.com)
}

\begin{abstract}
Abstrak - Usaha kuliner merupakan usaha yang memiliki peluang yang cukup besar di dunia industri, dapat dilihat dari aspek produk yang dijual dengan cara yang berbeda-beda mulai dari restaurant, café maupun konsep baru yang belakangan ini dikenal dengan food truck. Pemilik saat ini berjualan menggunakan bajaj dan dikeluhkan area kerja bagi pegawai yang kurang nyaman pada saat bekerja. Untuk itu pemilik berencana ingin memperluas usaha kulinernya dengan menggunakan food truck karena penjualannya yang semakin meningkat akhir-akhir ini dan memudahkan untuk menjangkau area pasar yang lebih luas. Tujuan dari penelitian ini adalah mendesain food truck dilihat dari perspektif penggunanya (pegawai dan pelanggan) berdasarkan metode Kano dengan mengusulkan rancangan fasilitas fisik yang ergonomis. Pengumpulan data mengenai kebutuhan dari customer (pegawai dan pelanggan) menggunakan kuesioner dengan model Garvin yaitu performance, features, reability, conformance, durability, serviceability, aesthetics, perceived quality. Kuesioner disebarkan kepada seluruh pegawai food truck dan 104 pelanggan yang pernah berbelanja di foodtruck. Hasil dari metode Kano diperoleh 16 atribut pelanggan dan 11 atribut pegawai yang dipentingkan dalam mendesain food truck sesuai dengan kebutuhan. Atribut-atribut tersebut akan dirancang dalam penelitian ini. Perancangan dilakukan menggunakan data-data yang dikumpulkan sebelumnya untuk merancang fasilitas fisik yaitu meja 1 berfungsi menerima pesanan dan take away, meja 2 berfungsi menjadi tempat membuat pesanan, meja pelanggan, meja mencuci piring, kursi pelanggan dan kursi pegawai.
\end{abstract}

Kata kunci: ergonomis; food truck; Kano

\section{PENDAHULUAN}

Kuliner kini tak sekadar hadir memenuhi kebutuhan dasar manusia, melainkan sebagai pengisi kegiatan bersantai dan gaya hidup. Usaha ini data dikatakan potensial, karena modal relatif terjangkau dan punya mobilisasi untuk berpindah tempat berjualan mengunjungi target pasar yang diinginkan. (Radar Bandung.id, 2019). Seiring berjalannya waktu maka permintaan akan food truck juga meningkat dan juga permintaan akan food truck juga berbeda-beda dengan mempertimbangkan kebutuhan pengusaha baik dari jenis makanan dan minuman yang dijual. Jenis makanan dan minuman yang berbeda tentunya memiliki kebutuhan yang berbeda baik dari segi bentuk dan juga ukuran dari food truck itu sendiri sesuai dengan kebutuhan. Saat ini pemilik usaha berjualan menggunakan bajaj, sehingga tidak cukup luas untuk pegawai membuat pesanan, karena kaki pegawai yang bekerja tidak dapat leluasa untuk bergerak dikarenakan ukuran yang tidak cukup luas untuk pegawai. Pemilik berencana ingin memperluas usaha kulinernya dengan menggunakan food truck karena penjualannya yang semakin meningkat akhir-akhir ini dan memudahkan untuk menjangkau area pasar yang lebih luas.

Perancangan yang baik harusnya bisa menjawab permasalahan aktivitas, kapasitas dan sinergisitas dari sebuah komponen perekonomian yang berkembang dalam siklus masyarakat (Putri Desy Dwi, Rangga Firmansyah, 2018). Tujuan penelitian ini untuk memberikan usulan rancangan food truck yang sesuai kebutuhan, dengan mempertimbangkan tempat untuk jenis dan banyaknya bahan baku yang diperlukan, tata letak food truck $\mathrm{x}$, fasilitas fisik yang mempertimbangkan kenyamanan pegawai saat melakukan pekerjaan, pencahayaan di dalam food truck $\mathrm{x}$ untuk menunjang kinerja pegawai, fasilitas fisik yang dibutuhkan pegawai dari segi ergonomi untuk meningkatkan rasa aman dan nyaman pegawai saat melakukan pekerjaan.

\section{STUDI LITERATUR}

Food truck adalah kegiatan menjual makanan/minuman dengan menggunakan media unit mobil yang dimodifikasi menyerupai dapur atau bar dan dilengkapi dengan alat penunjang usaha tersebut. Oleh karena 
menggunakan media unit mobil maka kegiatan berjualan, memiliki mobilitas yang dinamis. (Susilaningsih, 2018)

Kano (Kano, 1984 dalam (Ginting, 2016)) mengutarakan enam jenis kategori kebutuhan produk yang berpengaruh pada kepuasan pelanggan sebagai berikut:

1. Attractive: merupakan kategori yang tingkat kepuasan akan meningkat sangat tinggi dengan meningkatnya kinerja atribut.

2. One Dimensional: kategori yang apabila terpenuhi maka dapat meningkatkan kepuasan pelanggan dan akan menyebabkan ketidakpuasan bila tidak terpenuhi.

3. Must Be: merupakaan kategori dimana pelanggan menjadi tidak puas apabla kinerja dari atribut yang bersangkutan rendah tetapi kepuasan pelanggan tidak akan meningkat jauh di atas netral meskipun kinerja dari atribut tersebut tinggi. Kategori ini merupakan kebutuhan dasar yang harus dipenuhi.

4. Indifferent: terjadi jika ada maupun tidaknya layanan tidak akan memberikan pengaruh kepada kepuasan konsumen.

5. Reverse: merupakan kebalikan dari One Dimensional dimana apabila atribut terpenuhi maka dapat menurunkan kepuasan pelanggan atau dengan menurunkan kinerja atribut justru akan meningkatkan tingkat kepuasan pelanggan.

6. Questionable: merupakan kategori yang dipertanyakan, biasanya jawaban yang diberikan responden tidak jatuh dalam kategori ini.

\section{METODOLOGI}

Langkah awal adalah melakukan wawancara mengenai informasi menu minuman yang dijual, pendataan bahan baku, peralatan yang diperlukan di dalam food truck ini dan data kecelakaan kerja yang pernah terjadi dan berpotensi terjadi. Selanjutnya, identifikasi kebutuhan pelanggan dan pegawai untuk mengetahui needs dengan menentukan atribut dan menterjemahkannya ke dalam beberapa pernyataan. Perancangan kuesioner berpatokan pada delapan dimensi kualitas produk (Garvin, 1987) yang mewakili kebutuhan dari konsumen, yaitu performance, features, reability, conformance, durability, serviceability, aesthetics, perceived quality. Terdapat 26 atribut yang disusun dalam pernyataan positif '(fungsional) dan pernyataan yang bersifat negative (disfungsional). Penyebaran kuesioner dilakukan kepada seluruh pegawai dan 104 pelanggan dimana tiap pertanyaan, baik fungsional dan disfunctional. Dalam kuesioner, penilaian yang digunakan yaitu $1=$ suka, $2=$ mengharapkan, $3=$ netral, $4=$ toleransi, dan $5=$ tidak suka. Penyebaran kuesioner bertujuan untuk mengetahui kebutuhan fasilitas fisik dari perspektif konsumen baik dari segi eksterior, fasilitas fisik hingga fasilitas Kesehatan dan Keselamatan Kerja (K3) food truck x. Selain disebarkan kepada pelanggan, kuesioner juga diberikan kepada pegawai untuk mengetahui kebutuhan fasilitas fasilitas fisik dan data dari Kesehatan dan Keselamatan Kerja (K3). Teknik sampling yang digunakan adalah metode Purposive Sampling. Teknik penentuan sampel ini dengan cara menentukan ciri-ciri khusus yang sesuai dengan tujuan dari penelitian ini yaitu responden yang pernah membeli yang pernah membeli minuman di food truck minimum 1x (kali). Sedangkan pengambilan sampel pada pegawai, dilakukan sampling jenuh atau yang sering disebut total sampling (Sugiyono, 2002). Sebelum data disebarkan, dilakukan validitas konstruk terlebih dahulu.

Setelah data terkumpul, data dilanjutkan untuk pengujian validitas dan realibilitas. Jawaban pada kuesioner yang diinputkan pada tabel evaluasi metode Kano kemudian dihitung berdasarkan persyaratan Kano (Ginting Rosnani, I. Siregar, and T. U. H. Ginting, 2015). Setelah menentukan klasifikasi, selanjutnya mengelompokkan dan menghitung dari hasil klasifikasi yang sudah didapatkan sehingga untuk langkah ini hanya menentukan jumlah kategori Kano tiap-tiap atribut terhadap semua responden yang sudah didapatkan. Setelah didapatkan jumlah/nilai dari tiap-tiap kategorti atribut terhadap semua responden maka dilakukan penentuan kategori Kano dengan menggunakan rumus Blauth,s formula (Walden, 1993). Hasil klasifikasi kebutuhan berdasarkan metoda kano, akan dijadikan masukan dalam usulan desain food truck dengan dikombinasikan dengan data antropometri sehingga desain menjadi ergonomis. Perancangan fasilitas fisik ini juga mempertimbangkan tata letak dari fasilitas fisik yang dirancang dan ukuran kabin yang akan digunakan dalam penelitian ini, sehingga fasilitas yang dirancang akan sesuai baik dari tata letak fasilitas fisik dan ukuran kabin food truck. Analisis antropometri dalam desain fasilitas menggunakan konsep persentil yaitu 5\% untuk persentil minimum, 50\% untuk persentil rata-rata, dan 95\% untuk persentil maksimum, dan data antropometri orang dewasa yang diambil dari buku ergonomi dengan judul "Konsep Dasar dan Aplikasinya” (Nurmianto, 2008). 


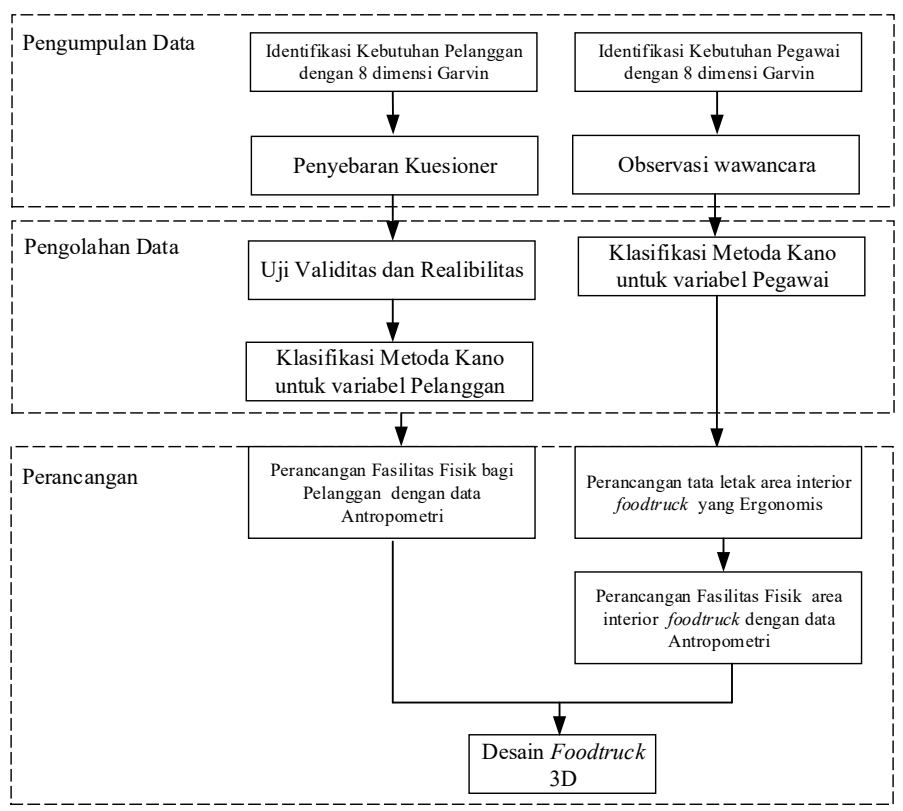

Gambar 1. Alur Penelitian

\section{HASIL DAN DISKUSI}

Kendaraan yang akan digunakan adalah UD Trucks Kuzer RKE 150 WB3350. Hasil kuesioner yang sudah disebarkan kepada seluruh pegawai dan 104 pelanggan akan diolah dengan menggunakan metode kano, namun sebelum diolah menggunakan metode kano akan di uji validitas dan reliabilitas terlebih dahulu. Setelah melakukan pengujian menggunakan SPSS, semua item indikator yang ada pada atribut menunjukkan bahwa R-hitung diatas 0,3 maka semua item dapat dikatakan valid. Hasil reliabilitas adalah reliabel dapat diihat dengan hasil dari Cronbach's Alpha adalah lebih besar dari 0.6. Berikut adalah hasil metode Kano, dari 26 atribut masing-masing, hanya 11 atribut pegawai dan 16 atribut pelanggan yang akan menjadi masukan dalam perancangan desain pada food truck. Kategori kano yang menjadi masukan dalam perancangan desain adalah attractive, One-Dimensional, dan Must Be., sedangkan untuk kategori indifferent, reverse, questionable tidak akan dipertimbangkan karena ketidakmampuan variabel untuk mempengaruhi kepuasan responden (Gupta, P., \& Srivastava, R. K. , 2012).

Tabel 1

Hasil Metoda Kano

\begin{tabular}{|c|c|l|c|}
\hline No & No. Atribut & \multicolumn{1}{|c|}{ Atribut Pelanggan } & Kategori KANO \\
\hline 1 & 1 & Ketersediaan area dine in & one dimensional \\
\hline 2 & 2 & $\begin{array}{l}\text { Ketersediaan fasilitas fisik (meja dan kursi) yang } \\
\text { nyaman (Dimensi yang sesuai dengan } \\
\text { penggunanya) }\end{array}$ & attractive \\
\hline 3 & 3 & Ketersediaan area tempat pemesanan & attractive \\
\hline 4 & 4 & $\begin{array}{l}\text { Ketersediaan area menunggu untuk take away di } \\
\text { Food Truck }\end{array}$ & one dimensional \\
\hline 5 & 5 & Ketersediaan menu pada tempat pemesanan & one dimensional \\
\hline 6 & 6 & Ketersediaan asbak di meja & attractive \\
\hline 7 & 7 & Ketersediaan fasilitas wifi & attractive \\
\hline 8 & 14 & $\begin{array}{l}\text { Ketersediaan mika pelindung dan pembatas } \\
\text { antara pegawai dan konsumen di Food Truck }\end{array}$ & attractive \\
\hline 9 & 17 & $\begin{array}{l}\text { Fasilitas fisik (Meja dan kursi) dapat mudah } \\
\text { dibersihkan }\end{array}$ & one dimensional \\
\hline 10 & 18 & Ketersediaan jumlah kursi yang cukup & attractive \\
\hline 11 & 19 & $\begin{array}{l}\text { Luas kanopi sesuai dengan luas operasional } \\
\text { attractive }\end{array}$ \\
\hline 12 & 20 & $\begin{array}{l}\text { Ketersediaan meja konsumen dengan material } \\
\text { yang kuat }\end{array}$ & attractive \\
\hline 13 & 21 & $\begin{array}{l}\text { Ketersediaan kursi konsumen dengan material } \\
\text { yang kuat }\end{array}$ & attractive \\
\hline 14 & 22 & $\begin{array}{l}\text { Ketersediaan kotak di Food Truck untuk } \\
\text { menampung keluhan konsumen }\end{array}$ & attractive \\
\hline 15 & 24 & $\begin{array}{l}\text { Eksterior Food Truck sesuai dengan tema } \\
\text { perusahaan }\end{array}$ & attractive \\
\hline 16 & 25 & Ketersediaan informasi halal & must be \\
\hline
\end{tabular}


Dari perhitungan diketahui bahwa atribut yang diinginkan adalah 27 atribut yang dibagi ke dalam 4 kategori perancangan yaitu fasilitas fisik dengan 15 atribut, eksterior dengan 3 atribut, layout dengan 7 atribut dan alat bantu lingkungan kerja dengan 1 atribut, maka dengan itu atribut-atribut ini akan menjadi dasar penulis dalam melakukan perancangan pada penelitian ini. Untuk itu rancangan fasilitas fisik yang dibutuhkan adalah meja 1 dan meja 2 dan tempat mencuci piring yang disertakan dengan laci sehingga dapat menyimpan barangbarang peralatan kerja didalam laci dan fasilitas lainnya yang dapat dilihat pada tabel 2.

Perancangan meja 1 ini diharapkan dapat menampung barang-barang perlengkapan food truck. Meja ini dirancang menggunakan kayu, agar design dari interior dalam food truck terkesan minimalis sehingga pegawai yang bekerja merasa nyaman ketika di dalam food truck ketika bekerja. Meja ini di design dengan ukuran pekerja yang sedang berdiri agar dapat menyesuaikan tinggi dan juga kenyamanan pegawai ketika melayani pelanggan. Perancangan fasilitas meja 2 ini diharapkan dapat memiliki fungsi selain meja untuk membuat minuman juga memiliki fungsi sebagai tempat penyimpanan bahan baku dari minuman dan alat-alat untuk membuat minuman. Peletakan bahan-bahan dan alat-alat pada tabel tersebut, diharapkan mempermudah pegawai dalam membuat minuman karena posisi yang dekat dengan pegawai bekerja. perancangan tempat penyimpanan pada meja 2 ini menggunakan dimensi dari barang yang akan disimpan sehingga barang yang akan disimpan akan muat ketika disimpan di dalam tempat penyimpanan.

Tabel 2

Atribut Kano Vs Kategori Perancangan

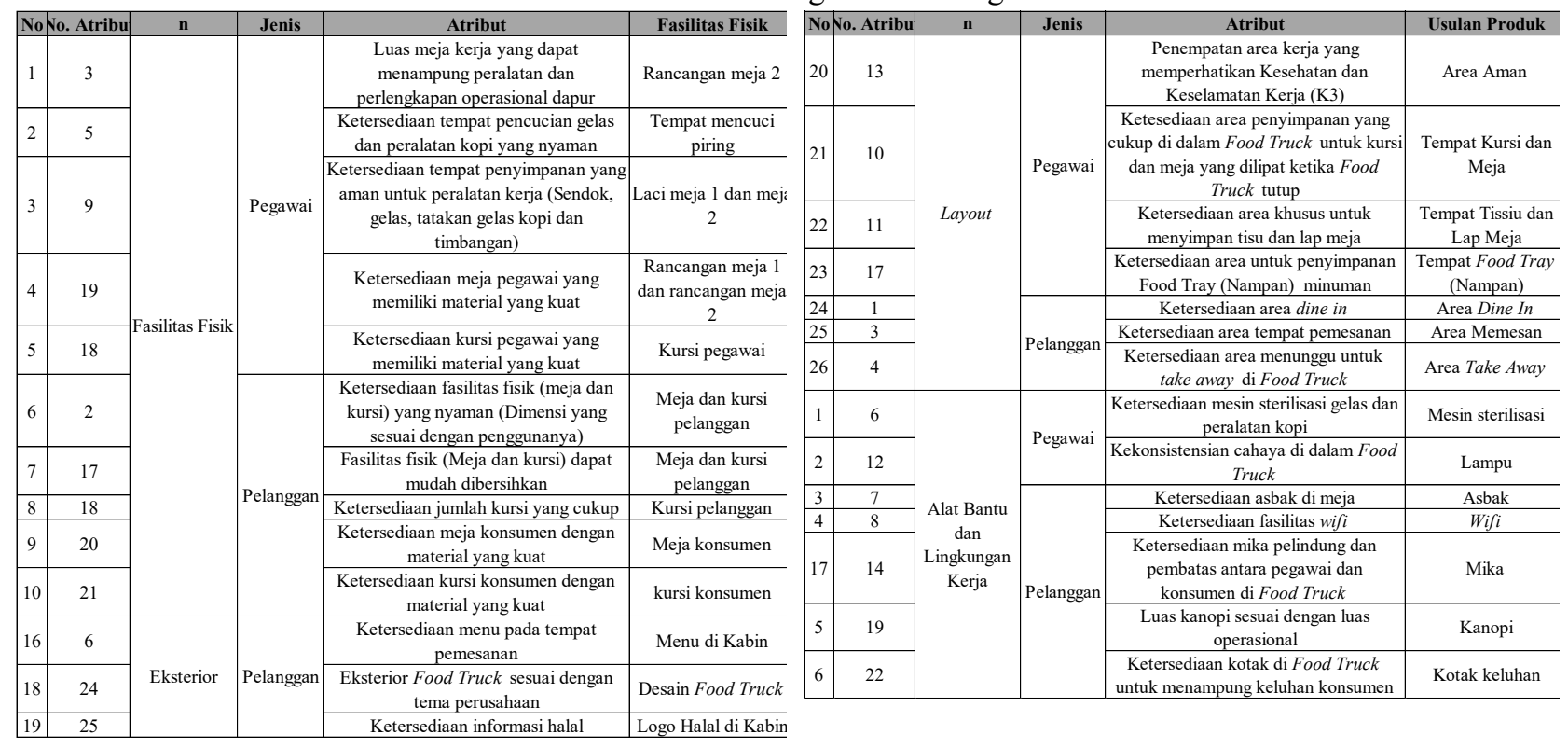

Tempat penyimpanan ini menggunakan dimensi dari barang yang akan disimpan dan juga menggunakan ukuran kenyamanan dari pegawai ketika mengambil barang tersebut, ukuran dari lebar setiap tempat penyimpanan menggunakan ukuran dari lebar meja 2, dikarenakan ukuran dari setiap barang-barang yang akan disimpan berbeda-beda sehingga akan membuat design dari meja 2 yang berantakan, sehingga ukuran dari setiap lebar tempat penyimpanan menggunakan ukuran maksimal yaitu ukuran lebar dari meja dapur rancangan, agar volume penyimpanan dapat maksimal. Perancangan kursi pelanggan ini, berfungsi untuk menjadi tempat duduk pelanggan yang menikmati minuman di tempat ataupun pelanggan yang akan menunggu minuman setelah memesan. Ukuran dari meja pelanggan ini menggunakan ukuran dari antropometri kenyamanan dari pelanggan, baik dari tinggi maupun lebar dari kursi pelanggan, tinggi dari alas kursi pelanggan ditambahkan allowance untuk sepatu, karena ketika pelanggan datang ke food truck menggunakan alas kaki sehingga allowance ini diberikan untuk alas kaki tersebut. Design dari kursi ini menggunakan design yang minimalis dengan menggunakan bahan dasar kayu dan besi sehingga selaras dengan tema dari perusahaan. Perancangan fasilitas fisik ini menggunakan data antropometri orang Indonesia dalam buku (Nurmianto, 2008).

Berikut adalah data antropometri yang digunakan untuk merancang meja 1. Untuk pembahasan dimensi fasilitas lain tidak dibahas karena keterbatasan area analisis. Meja rancangan ini memiliki panjang meja yang akan di bagi menjadi 2 bagian yaitu bagian A dan B, bagian yang A berfungsi sebagai tempat untuk take away, 
sehingga pelanggan yang memesan untuk take away akan mengambil pesanan disini dan bagian B yang berfungsi sebagai kasir, pegawai akan melayani pelanggan pada bagian ini untuk dine in atau pelanggan yang akan makan di tempat.

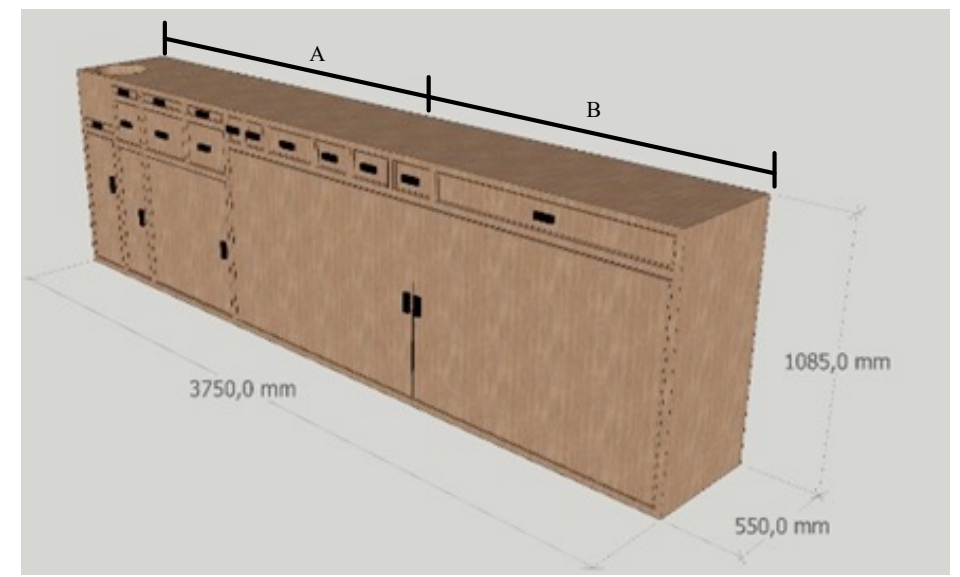

Gambar 2. Usulan Meja 1

Perancangan layout kabin pada food truck ini adalah dengan mempertimbangkan ukuran dari setiap fasilitas fisik dan juga fungsi dari setiap fasilitas fisik. Meja 1 akan diletakkan menghadap pelanggan yang sedang memesan, karena meja 1 berfungsi untuk menerima pesanan dari pelanggan yang mau take in atau juga yang mau take away. Setelah itu meja 2 akan diletakkan berseberangan dengan meja 1, karena meja 2 ini berfungsi untuk memproses pesanan yang dipesan oleh pelanggan dimana meja ini sebagai tempat pegawai untuk membuat pesanan. 
Tabel 3

Data Antropometri Meja 1

\begin{tabular}{|c|c|c|c|c|c|c|c|c|c|c|c|}
\hline \multirow[b]{2}{*}{ No } & \multirow[b]{2}{*}{ Bagian Produk } & & & \multirow[b]{2}{*}{ Dimensi } & \multicolumn{3}{|c|}{ Ukuran } & \multicolumn{2}{|l|}{ Allowance } & \multirow{2}{*}{$\begin{array}{c}\text { Ukuran yang } \\
\text { diusulkan } \\
(\mathrm{mm})\end{array}$} & \multirow[b]{2}{*}{$\begin{array}{l}\text { Ukuran } \\
\text { Terpilih }\end{array}$} \\
\hline & & \multicolumn{2}{|c|}{ Spesifikasi } & & $\begin{array}{c}\text { Jenis } \\
\text { Kelamin }\end{array}$ & Persentil & Ukuran (mm) & Jenis & $\begin{array}{l}\text { Ukuran } \\
\text { (mm) }\end{array}$ & & \\
\hline \multirow{6}{*}{1} & \multirow{6}{*}{$\begin{array}{c}\text { Alas rancangan meja } \\
1\end{array}$} & \multirow{2}{*}{ Tinggi } & Min & Tinggi siku berdiri & Pria & P5 & 932 & Sepatu & 20 & \multirow{2}{*}{$952-1025$} & \multirow{2}{*}{1025} \\
\hline & & & Max & Tinggi siku berdiri & Pria & $\mathrm{P} 50$ & 1003 & Sepatu & 20 & & \\
\hline & & \multirow[b]{2}{*}{ Panjang } & Min & $\begin{array}{l}\text { Jarak Bentang dari ujung jari } \\
\text { tangan kanan ke kiri }\end{array}$ & Pria & P95 & 1806 & - & - & \multirow[b]{2}{*}{$1806-3750$} & \multirow[b]{2}{*}{3750} \\
\hline & & & $\operatorname{Max}$ & $\begin{array}{c}\text { Panjang kabin kendaraan mobil } \\
\text { yang digunakan - panjang } \\
\text { westafel }\end{array}$ & - & - & $4500-750=3750$ & - & - & & \\
\hline & & \multirow[b]{2}{*}{ Lebar } & Min & Ukuran mesin kasir & - & - & 360 & - & - & \multirow[b]{2}{*}{$360-767$} & \multirow[b]{2}{*}{550} \\
\hline & & & $\operatorname{Max}$ & \begin{tabular}{|c|} 
Jarak genggaman tangan (grip) \\
ke punggung pada posisi tangan \\
ke depan (horizontal) \\
\end{tabular} & Pria & P95 & 767 & - & - & & \\
\hline \multirow{3}{*}{2} & \multirow{3}{*}{$\begin{array}{l}\text { Tempat Food tray } \\
\text { (Nampan) }\end{array}$} & Tinggi & - & Tinggi Food Tray (Nampan) & - & - & 20 & $\begin{array}{c}\text { Tebal tangan ketika } \\
\text { mengambil barang }\end{array}$ & 30 & 50 & 50 \\
\hline & & Panjang & - & Panjang Food Tray (Nampan) & - & - & 250 & $\begin{array}{c}\text { Tebal tangan ketika } \\
\text { mengambil barang }\end{array}$ & 30 & 280 & 280 \\
\hline & & Lebar & - & Lebar rancangan meja 1 & - & - & 550 & - & - & 550 & 550 \\
\hline \multirow{3}{*}{3} & \multirow{3}{*}{$\begin{array}{c}\text { Tempat penyimpanan } \\
\text { galon }\end{array}$} & Tinggi & - & 1/2 Tinggi galon & - & - & $500 / 2=250$ & - & - & 250 & 250 \\
\hline & & Panjang & - & Panjang galon & - & - & 250 & $\begin{array}{l}\text { Tebal tangan ketika } \\
\text { mengambil barang }\end{array}$ & 30 & 280 & 280 \\
\hline & & Lebar & - & Lebar galon & - & - & 250 & $\begin{array}{c}\text { Tebal tangan ketika } \\
\text { mengambil barang }\end{array}$ & 30 & 280 & 280 \\
\hline \multirow{3}{*}{4} & \multirow{3}{*}{$\begin{array}{c}\text { Tempat penyimpanan } \\
\text { galon cadangan }\end{array}$} & Tinggi & - & $\begin{array}{l}\text { rancangan meja } 1 \text { - tempat food } \\
\text { tray (Nampan) - tempat } \\
\text { penyimpanan galon }\end{array}$ & - & - & $1025-50-250=725$ & - & - & 725 & 725 \\
\hline & & Panjang & - & Panjang galon & - & - & 250 & $\begin{array}{c}\text { Tebal tangan ketika } \\
\text { mengambil barang }\end{array}$ & 30 & 280 & 280 \\
\hline & & Lebar & - & Lebar galon & - & - & 250 & $\begin{array}{c}\text { Tebal tangan ketika } \\
\text { mengambil barang }\end{array}$ & 30 & 280 & 280 \\
\hline \multirow{3}{*}{5} & \multirow{3}{*}{$\begin{array}{l}\text { Tempat penyimpanan } \\
\text { Cup minuman Dingin }\end{array}$} & Tinggi & - & Panjang Cup minuman dingin & - & - & 94 & $\begin{array}{c}\text { Tebal tangan ketika } \\
\text { mengambil barang }\end{array}$ & 30 & 124 & 124 \\
\hline & & Panjang & - & Panjang Cup minuman dingin & - & - & 94 & $\begin{array}{c}\text { Tebal tangan ketika } \\
\text { mengambil barang }\end{array}$ & 30 & 124 & 124 \\
\hline & & Lebar & - & Lebar rancangan meja 1 & - & - & 550 & - & - & 550 & 550 \\
\hline & & Tinggi & - & Panjang Cup minuman Panas & - & - & 80 & $\begin{array}{c}\text { Tebal tangan ketika } \\
\text { mengambil barang }\end{array}$ & 30 & 110 & 110 \\
\hline 6 & Cup minuman Panas & Panjang & - & Panjang Cup minuman Panas & - & - & 80 & $\begin{array}{l}\text { Tebal tangan ketika } \\
\text { mengambil barang }\end{array}$ & 30 & 110 & 110 \\
\hline & & Lebar & - & Lebar rancangan meja 1 & - & - & 550 & - & - & 550 & 550 \\
\hline & Tempat penvimpanan & Tinggi & - & $\begin{array}{c}\text { Panjang Tutup Cup minuman } \\
\text { Panas }\end{array}$ & - & - & 80 & $\begin{array}{l}\text { Tebal tangan ketika } \\
\text { mengambil barang }\end{array}$ & 30 & 110 & 110 \\
\hline 7 & $\begin{array}{l}\text { tutup Cup minuman } \\
\text { Panas }\end{array}$ & Panjang & - & $\begin{array}{c}\text { Panjang Tutup Cup minuman } \\
\text { Panas }\end{array}$ & - & - & 300 & - & - & 300 & 300 \\
\hline & & Lebar & - & Lebar Tutup cup minuman panas & - & - & 80 & $\begin{array}{l}\text { Tebal tangan ketika } \\
\text { mengambil barang }\end{array}$ & 30 & 110 & 110 \\
\hline & & Tinggi & - & panjang kantong plastik x 100 & - & - & $1 * 100=100$ & - & - & 100 & 100 \\
\hline 8 & Kantono nlastik & Panjang & - & Tinggi kantong plastik & - & - & 195 & - & - & 195 & 195 \\
\hline & & Lebar & - & Lebar rancangan meja 1 & - & - & 550 & - & - & 550 & 550 \\
\hline & Tempat penyimpanan & Tinggi & - & Tinggi Tempat Tissiu & - & - & 86 & $\begin{array}{l}\text { Tebal tangan ketika } \\
\text { mengambil barang }\end{array}$ & 30 & 116 & 116 \\
\hline 9 & $\begin{array}{c}\text { Tissiu dan Tempat } \\
\text { Tissiu }\end{array}$ & Panjang & - & $\begin{array}{c}\text { Panjang Tissiu + Panjang Tempat } \\
\text { Tissiu } \\
\end{array}$ & - & - & $100+110=210$ & - & - & 210 & 210 \\
\hline & & Lebar & - & Lebar rancangan meja 1 & - & - & 550 & - & - & 550 & 550 \\
\hline
\end{tabular}


Tabel 3

Data Antropometri Meja 1(Lanjutan)

\begin{tabular}{|c|c|c|c|c|c|c|c|c|c|c|c|}
\hline \multirow[b]{2}{*}{ No } & \multirow[b]{2}{*}{ Bagian Produk } & \multirow{2}{*}{\multicolumn{2}{|c|}{ Spesifikasi }} & \multirow[b]{3}{*}{2 Lebar celmek } & \multicolumn{3}{|c|}{ Ukuran } & \multicolumn{2}{|l|}{ Allowance } & \multirow{2}{*}{$\begin{array}{l}\text { Ukuran yang } \\
\text { diusulkan } \\
(\mathrm{mm})\end{array}$} & \multirow{2}{*}{$\begin{array}{r}\text { Ukuran } \\
\text { Terpilih }\end{array}$} \\
\hline & & & & & Jenis & Persentil & Ukuran (mm) & Jenis & Ukuran & & \\
\hline \multirow{3}{*}{10} & \multirow{3}{*}{$\begin{array}{c}\text { Tempat penyimpanan } \\
\text { celmek }\end{array}$} & Tinggi & - & & - & - & $2 * 30=60$ & & & \begin{tabular}{|l|}
60 \\
\end{tabular} & 60 \\
\hline & & Panjang & - & $\begin{array}{l}\text { Panjang celmek }+1 / 3 \text { panjang } \\
\text { celmek }\end{array}$ & - & - & $690+230=920$ & - & - & 920 & 920 \\
\hline & & Lebar & - & Lebar rancangan meja 1 & - & - & 550 & - & - & 550 & 550 \\
\hline \multirow{3}{*}{11} & \multirow{3}{*}{$\begin{array}{c}\text { Tempat penyimpanan } \\
\text { alat variasi kopi (Drip } \\
\text { Coffe maker, moka } \\
\text { pot dan vietnam drip) }\end{array}$} & Tinggi & - & Tinggi Moka Pot & - & - & 182 & $\begin{array}{c}\text { Tebal tangan ketika } \\
\text { mengambil barang }\end{array}$ & 30 & 212 & 212 \\
\hline & & Panjang & - & $\begin{array}{c}\text { Lebar drip coffe maker + moka } \\
\text { pot + vietnam drip }\end{array}$ & - & - & $100+80+90=270$ & $\begin{array}{l}\text { Tebal tangan ketika } \\
\text { mengambil barang }\end{array}$ & 30 & 300 & 300 \\
\hline & & Lebar & - & Lebar rancangan meja 1 & - & - & 550 & - & - & 550 & 550 \\
\hline \multirow{3}{*}{12} & \multirow{3}{*}{$\begin{array}{c}\text { Tempat penyimpanan } \\
\text { alat pendukung } \\
\text { variasi kopi milk jug, } \\
\text { Server, catel, shaker } \\
\text { dan jigger }\end{array}$} & Tinggi & - & Tinggi catel & - & - & 188 & $\begin{array}{c}\text { Tebal tangan ketika } \\
\text { mengambil barang }\end{array}$ & 30 & 218 & 218 \\
\hline & & Panjang & - & Lebar milk jug + server + catel & - & - & $130+85+190=405$ & $\begin{array}{c}\text { Tebal tangan ketika } \\
\text { mengambil barang }\end{array}$ & 30 & 435 & 435 \\
\hline & & Lebar & - & Lebar rancangan meja 1 & - & - & 550 & - & - & 550 & 550 \\
\hline \multirow{3}{*}{13} & \multirow{3}{*}{$\begin{array}{c}\text { Tempat penyimpanan } \\
\text { timbangan kopi dan } \\
\text { tamper }\end{array}$} & Tinggi & - & Tinggi catel & - & - & 188 & $\begin{array}{c}\text { Tebal tangan ketika } \\
\text { mengambil barang }\end{array}$ & 30 & 218 & 218 \\
\hline & & Panjang & - & Lebar timbangan kopi + tamper & - & - & $193+125=318$ & $\begin{array}{c}\text { Tebal tangan ketika } \\
\text { mengambil barang }\end{array}$ & 30 & 348 & 348 \\
\hline & & Lebar & - & Lebar rancangan meja 1 & - & - & 550 & - & - & 550 & 550 \\
\hline \multirow{3}{*}{14} & \multirow{3}{*}{$\begin{array}{c}\text { Tempat Penyimpanan } \\
\text { Tempat Sampah }\end{array}$} & Tinggi & - & $\begin{array}{c}\text { Tinggi rancangan meja } 1 \text { - } \\
\text { Tempat penyimpanan alat } \\
\text { pendukung variasi kopi - Tempat } \\
\text { penyimpanan celmek }\end{array}$ & - & - & $1025-218-60=747$ & & & 747 & 747 \\
\hline & & Panjang & - & \begin{tabular}{|c|}
$\begin{array}{c}\text { Tempat penyimpanan alat } \\
\text { pendukung variasi kopi }\end{array}$ \\
\end{tabular} & - & - & 335 & & & 335 & 335 \\
\hline & & Lebar & - & Lebar rancangan meja 1 & - & - & 550 & - & - & 550 & 550 \\
\hline \multirow{3}{*}{15} & \multirow{3}{*}{$\begin{array}{c}\text { Tempat Penyimpanan } \\
\text { Alat pembersih }\end{array}$} & Tinggi & - & $\begin{array}{c}\text { Tinggi rancangan meja } 1 \text { - } \\
\text { Tempat penyimpanan alat } \\
\text { pendukung variasi kopi - Tempat } \\
\text { penyimpanan celmek }\end{array}$ & - & - & $1025-218-60=747$ & - & - & 747 & 747 \\
\hline & & Panjang & - & $\begin{array}{c}\text { Tempat penyimpanan timbangan } \\
\text { kopi dan tamper + Tempat } \\
\text { penyimpanan alat variasi kopi }\end{array}$ & - & - & $335+300=635$ & - & & 635 & 635 \\
\hline & & Lebar & - & Lebar rancangan meja 1 & - & - & 550 & - & - & 550 & 550 \\
\hline \multirow{6}{*}{16} & \multirow{6}{*}{$\begin{array}{l}\text { Tempat Menyimpan } \\
\text { Uang }\end{array}$} & \multirow{2}{*}{ Tinggi } & Min & 1/2 Panjang tangan & Pria & P50 & $176 / 2=88$ & - & - & \multirow{2}{*}{$88-176$} & \multirow{2}{*}{124} \\
\hline & & & Max & Panjang tangan & Pria & $\mathrm{P} 50$ & 176 & & - & & \\
\hline & & & Min & 5 Lebar uang kertas & - & - & $5 * 65=325$ & - & & & \\
\hline & & Panjang & $\operatorname{Max}$ & $\begin{array}{c}\text { Panjang rancangan meja } 1 \text { - } \\
\text { tempat penyimpanan food tray } \\
\text { (nampan) - tempat penyimpanan } \\
\text { celmek - tempat penyimpanan } \\
\text { cup minuman dingin - tempat } \\
\text { penyimpanan cup minuman panas } \\
\text { - tempat penyimpanan tutup cup } \\
\text { minuman panas - tempat } \\
\text { penyimpanan plastik - tempat } \\
\text { penyimpanan tissiu dan tempat } \\
\text { tissiu) }\end{array}$ & - & - & $\left|\begin{array}{c}3750-280-350-940- \\
124-110-110-169- \\
220-(11 * 30)=917\end{array}\right|$ & - & - & $325-1117$ & 1117 \\
\hline & & \multirow{2}{*}{ Lebar } & Min & \begin{tabular}{|c|} 
Panjang Uang kertas \\
\end{tabular} & - & - & 151 & - & \multirow[t]{2}{*}{ - } & $151-550$ & 550 \\
\hline & & & Max & Lebar rancangan meja 1 & - & - & 550 & - & & $151-550$ & 550 \\
\hline & & Tinggi & - & \begin{tabular}{|c|} 
Tinggi rancangan meja 1 - \\
Tempat penyimpanan cup \\
minuman dingin
\end{tabular} & - & - & $1025-124=901$ & - & - & 901 & 901 \\
\hline 17 & $\begin{array}{l}\text { Tempat Menyimpan } \\
\text { Air Bersih }\end{array}$ & Panjang & - & \begin{tabular}{|} 
Panjang rancangan meja 1- \\
Panjang Tempat penyimpan alat \\
pembersih - Panjang tempat \\
penyimpan tempat sampah - \\
Panjang tempat penyimpan galon \\
cadangan \\
\end{tabular} & - & - & $\begin{array}{c}3750-363-335-280 \\
=2772\end{array}$ & - & - & 2772 & 2772 \\
\hline & & Lebar & - & \begin{tabular}{|l|} 
Lebar rancangan meja 1 \\
\end{tabular} & - & - & 550 & - & - & 550 & 550 \\
\hline & & Panjang & Min & Panjang tangan & Pria & P50 & 176 & - & - & $79-87$ & 87 \\
\hline 18 & Handle laci meja & & $\operatorname{Max}$ & Panjang tangan & Pria & P95 & 191 & - & - & & \\
\hline & kasir + take away & Lebar & \begin{tabular}{|l|} 
Min \\
Max \\
\end{tabular} & $\begin{array}{l}\text { 1/2 Lebar tangan } \\
1 / 2 \text { Lebar tangan }\end{array}$ & $\begin{array}{l}\text { Pria } \\
\text { Pria }\end{array}$ & $\begin{array}{l}\text { P50 } \\
\text { P95 }\end{array}$ & $\begin{array}{l}40 \\
44\end{array}$ & $\begin{array}{l}- \\
-\end{array}$ & $\begin{array}{l}- \\
-\end{array}$ & $40-44$ & 44 \\
\hline
\end{tabular}

Fasilitas fisik selanjutnya adalah kulkas, kulkas ini diletakkan bersebelahan dengan meja 2, karena akan mempermudah pegawai untuk mengambil bahan-bahan yang ada di lemari pendingin atau kulkas, sehingga kulkas ini harus berdekatan dengan meja 2. Kursi pegawai diletakkan di tengah-tengah meja 1 dan meja 2, karena untuk mempermudah pegawai untuk beristirahat dan juga berdiri ketika mau bekerja kembali karena tidak terhalang fasilitas fisik yang lain. Fasilitas terakhir adalah meja mencuci piring, meja ini diletakkan di bagian kabin yang berdekatan dengan sumber air dari meja mencuci piring ini, sehingga mekanisme air dari 
tempat penampungan dan juga tempat air keluar tidak akan sulit karena berdekatan dengan sumber. Adapun hasil dari perancangan layout food truck sebagai berikut:

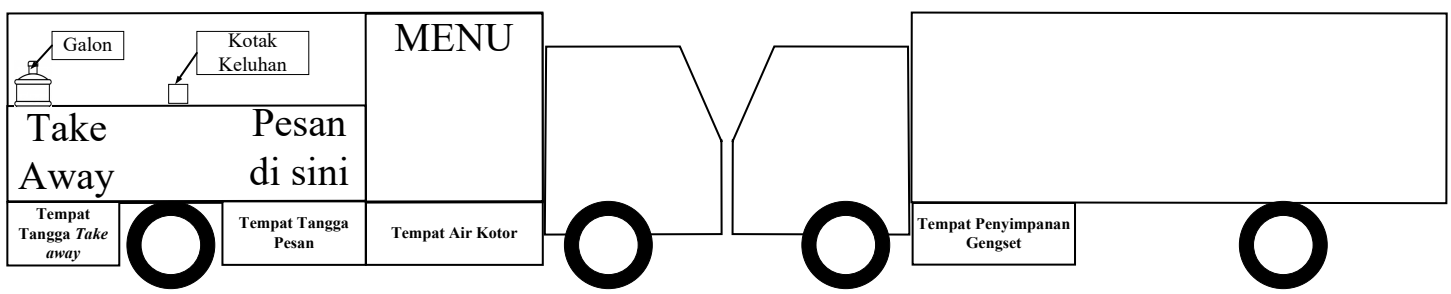

Gambar 3. Layout 2D food truck tampak kiri dan kanan

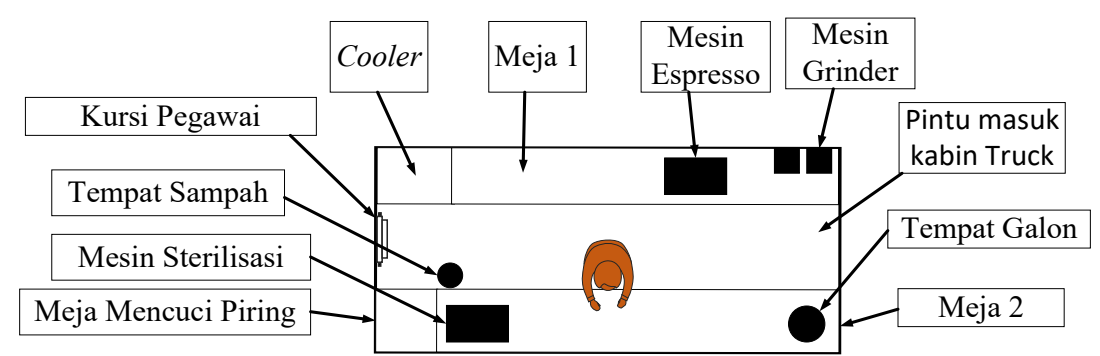

Gambar 4. Layout 2D food truck tampak Atas

Mesin-mesin yang ada di atas meja seperti mesin espresso, mesin grinder, mesin sterilisasi dan mesin cupseler akan aman ketika mobil truck berjalan, karena meja dari meja 1 dan meja 2 bertekstur kasar yang memungkinkan menahan mesin-mesin tersebut bergeser ketika mobil truck berjalan. Penampungan air diletakkan di bagian bawah kabin food truck, sehingga air akan lebih mudah turun menuju tempat penampungan air. Tangga untuk pesan minuman diletakkan bersebelahan dengan tempat penampungan air dengan ukuran dari tangga telah di rancang dan juga tangga take away yang diletakkan di belakang ban food truck, tangga pesan dan tangga take away dirancang dan ditambahkan tulisan sebagai informasi tempat memesan dan juga take away.

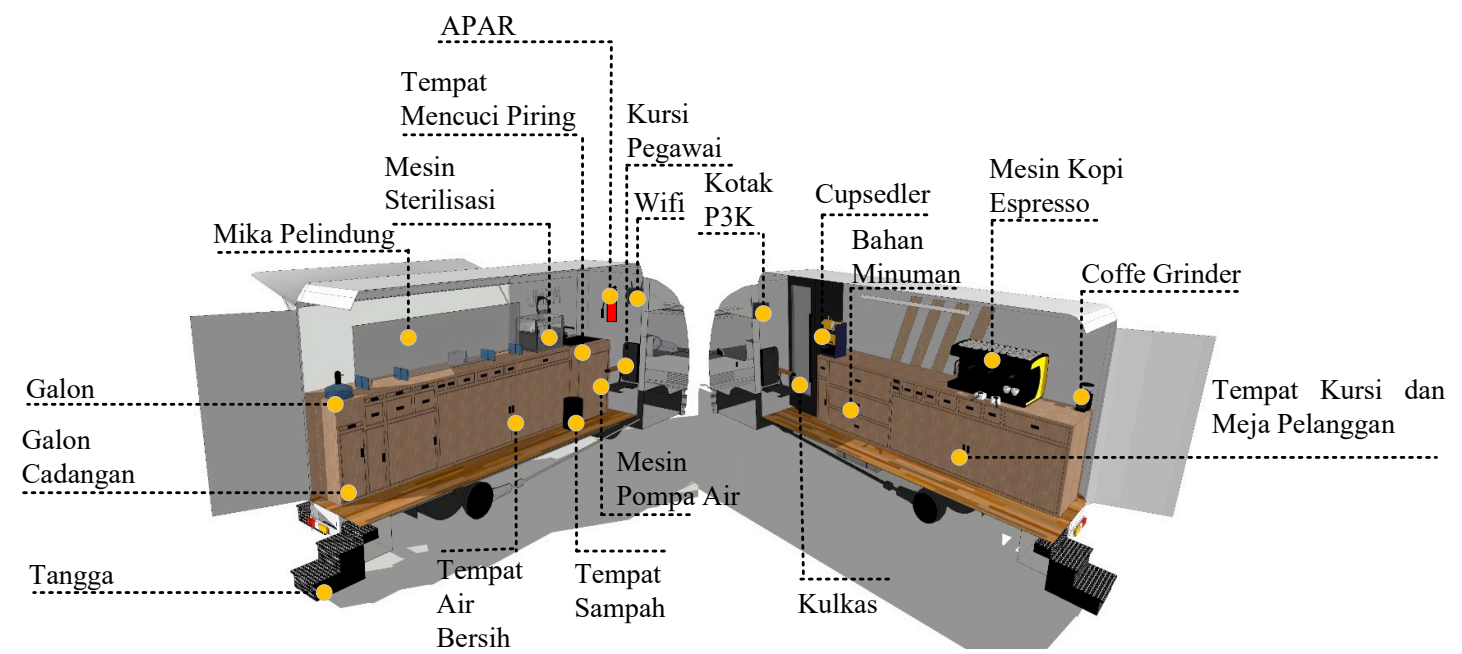

Gambar 5. Layout food truck Sisi kanan dan kiri 


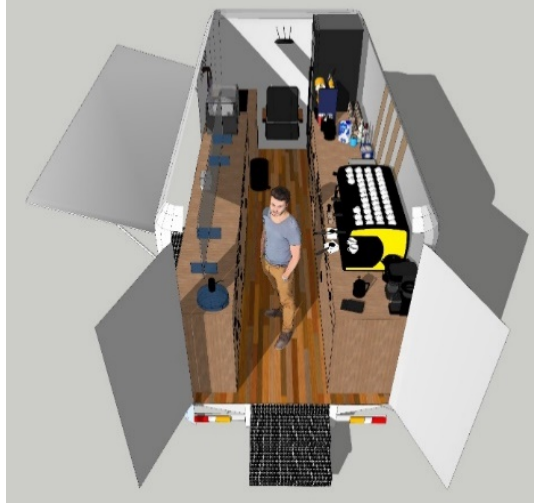

Gambar 6. Food Truck Tampak Atas

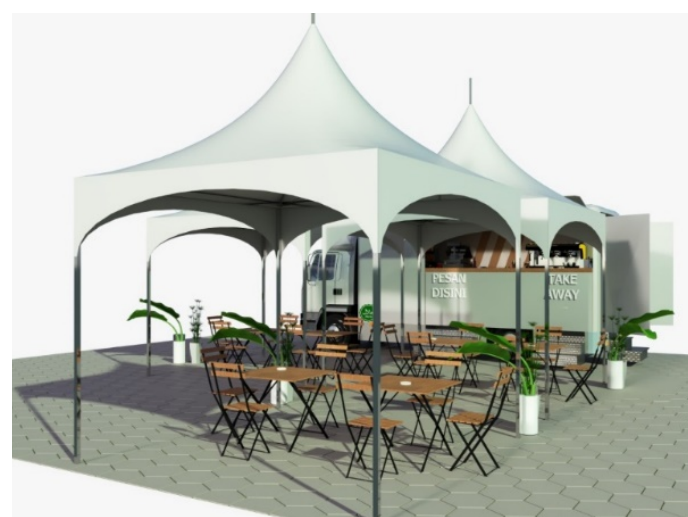

Gambar 7. Food Truck Keadaan Terbuka

\section{KESIMPULAN}

Hasil dari atribut yang diperoleh dari metode Kano pada tabel 2 mengenai ketersediaan area dine in, fasilitas fisik (meja dan kursi) yang nyaman (dimensi yang sesuai dengan penggunanya), area tempat pemesanan, area menunggu untuk take away di food truck telah dirancang secara ergonomis. Menu pada tempat pemesanan pada rancangan food truck telah sejalur dengan area pemesanan. Ketersediaan asbak di meja, fasilitas wifi, kotak keluhan pelanggan dirancang sebagai fasilitas tambahan telah dirancang. Ketersediaan mika pelindung dan pembatas antara pegawai dan konsumen di food truck telah diusulkan. Fasilitas fisik (Meja dan kursi) menggunakan material yang kuat dan ringan. Eksterior food truck sesuai dengan tema perusahaan, dimana material ini menggunakan material kayu yang sesuai dengan tema perusahaan yaitu vintage. Ketersediaan informasi halal, dimana terdapat logo halal pada kabin food truck yang berarti usaha ini halal. Luas meja kerja yang dapat menampung peralatan dan perlengkapan operasional dapur, perancangan meja ini dirancang menggunakan ukuran yang nyaman dan cukup untuk menampung peralatan dan perlengkapan operasional dapur. Ketersediaan tempat pencucian gelas dan peralatan kopi yang ergonomis, dirancang khusus untuk merancang tempat pencucian gelas dan peralatan kopi. Ketersediaan mesin sterilisasi gelas dan peralatan kopi, tempat penyimpanan yang aman untuk peralatan dimana setiap peralatan kerja akan disimpan di laci-laci. Ketersediaan area penyimpanan yang cukup di dalam food truck untuk bangku dan meja yang dilipat ketika food truck tutup. Ketersediaan area khusus untuk menyimpan tisu dan lap meja, perancangan area ini meja 1 dan meja 2 . Jumlah lampu yang dibutuhkan di dalam food truck adalah 1 , dimana kebutuhan lux di dalam food truck adalah 300 lux untuk pekerjaan rutin (KEPUTUSAN KEMENTRIAN KESEHATAN REPUBLIK INDONESIA No 1405/MENKES/SK/XI/02, 2002). Penempatan area kerja yang memperhatikan Kesehatan dan Keselamatan Kerja (K3), yaitu tersedia APAR dan kotak P3K. Ketersediaan area untuk penyimpanan food tray (nampan) minuman, area penyimpanan pada rancangan meja 1. Ketersediaan kursi pegawai dan meja pegawai yang memiliki material yang kuat.

\section{DAFTAR PUSTAKA}

Ginting Rosnani, I. Siregar, and T. U. H. Ginting. (2015). Perancangan alat penyadap karet di Kabupaten Langkat Sumatera Utara dengan Metode Quality Function deployment (QFD) dan Model Kano. J@ $t i$ Undip: Jurnal Teknik Industri, vol. 10, pp. 33-40.

Garvin, D. A. (1987). Managing Quality. New York: The Free Press.

Ginting, R. (2016). Quality Function Deployment. Medan: USU Press.

Gupta, P., \& Srivastava, R. K. . (2012). Analysis of customer satisfaction of the hotel industry in India using Kano Model \& QFD. IJRCM , 74-81.

KEPUTUSAN KEMENTRIAN KESEHATAN REPUBLIK INDONESIA No 1405/MENKES/SK/XI/02. (2002). Persyaratan Kesehatan Lingkungan Kerja Perkantoran dan Industri. Jakarta: Menteri Kesehatan Republik Indonesia.Persyaratan Kesehatan Lingkungan Kerja Perkantoran dan Industri. Jakarta: Menteri Kesehatan Republik Indonesia.

Nurmianto, E. (2008). Ergonomi Konsep Dasar dan Aplikasinya. Surabaya: Guna Widya. 
Putri Desy Dwi \& Rangga Firmansyah. (2018). Analisa Furtinur sebagai Media Duduk pda Area Foodtruck. Jurnal IDEALOG Ide dan Dialog Indonesia, halaman 12-22; Vol 3 Nomor 2 doi.org/10.25124/idealog.v3i2.1440.

RadarBandung.id. (2019). Perkembangan Bisnis Food Truk di Bandung Kian Mudah Dijangkau. Bandung: https://www.radarbandung.id/2019/07/01/perkembangan-bisnis-food-truk-di-bandung-kian-mudahdijangkau/.

Sugiyono. (2002). Metodologi Penelitian Bisnis. Bandung: Alfabeta.

Susilaningsih, L. R. (2018). Panduan Pendirian Usaha Foodtruck . Badan Ekonomi Kreatif bekerjasama dengan Universitas Sebelas Maret.

Walden, D. (1993). A Special Issue on Kano's Methods for Understanding Customer Defined. The Center for Quality of Management Journal, pp. 3-35. 